\title{
Efficiency of eggshell as a low-cost adsorbent for removal of cadmium: Kinetic and isotherm studies
}

\author{
Kahina Annane $^{*}$, Wahiba Lemlikchi ${ }^{a, b}$, Sophie Tingry ${ }^{c}$
}

${ }^{a}$ Laboratoire de Chimie Appliquée et de Génie Chimique, Université Mouloud Mammeri TiziOuzou, Algeria

${ }^{b}$ Laboratory of Materials and Environmental Sciences, Faculty of Sciences, University Algiers 1, Algiers center, 16000, Algeria

${ }^{c}$ Institut Européen des Membranes - ENSCM/UM2/CNRS 5635, IEM/UM2, CC 047, Place Eugène Bataillon, F-34095, Montpellier Cedex 5, France

* E-mail address Corresponding author:

kahina.annane@ummto.dz (ANNANE K) 


\title{
Efficiency of eggshell as a low-cost adsorbent for removal of cadmium: Kinetic and isotherm studies
}

\begin{abstract}
Eggshell (ES) is an alternative source of calcium carbonate that efficiently removes heavy metals in aqueous solution. The adsorption capacity of ES depends on their physicochemical properties and the influence of experimental conditions, but in the majority of reports, not all the reaction parameters related to adsorption process of heavy metals are available, and the adsorption mechanism is not systematically studied. In this contribution, the use of ES waste is reported to establish an overall performance trend of the experimental parameters on cadmium ion $\left(\mathrm{Cd}^{2+}\right)$ adsorption from an aqueous solution. Different physicochemical techniques Brunauer-Emmett-Teller (BET), Fourier transform infrared (FTIR) spectroscopy, scanning electron microscopy (SEM), thermogravimetric analysis (TGA) and X-ray diffraction (RXD) are used to characterize the physico-chemical properties of ES and the adsorption performance are studied as a function of contact time, $\mathrm{pH}$, concentration and adsorbent dosage. The highest adsorption capacity, $217.4 \mathrm{mg} \cdot \mathrm{g}^{-1}$, obtained in $10 \mathrm{~min}$ at an initial $\mathrm{pH}=5$ with an adsorbent dose of $0.8 \mathrm{~g} \cdot \mathrm{L}^{-1}$, is mainly attributed to the high specific surface area of the eggshell used in this work. Adsorption kinetics are described by the pseudo-second-order model, in good agreement with the experimental data, and the sorption mechanism follows the isotherm model of Langmuir, characterized by the chemical adsorption of a homogeneous monolayer of $\mathrm{Cd}^{2+}$ on the surface of ES adsorbents. The desorption efficiency of cadmium ions is efficient in the presence of nitric acid. The outcomes provided by the study confirm the use of eggshell as an effective and inexpensive material, offering high efficiency for cadmium removal.
\end{abstract}

Keywords: Eggshell, Adsorption, Cadmium ions removal, kinetic, isotherm, Desorption. 


\section{Graphical Abstract}

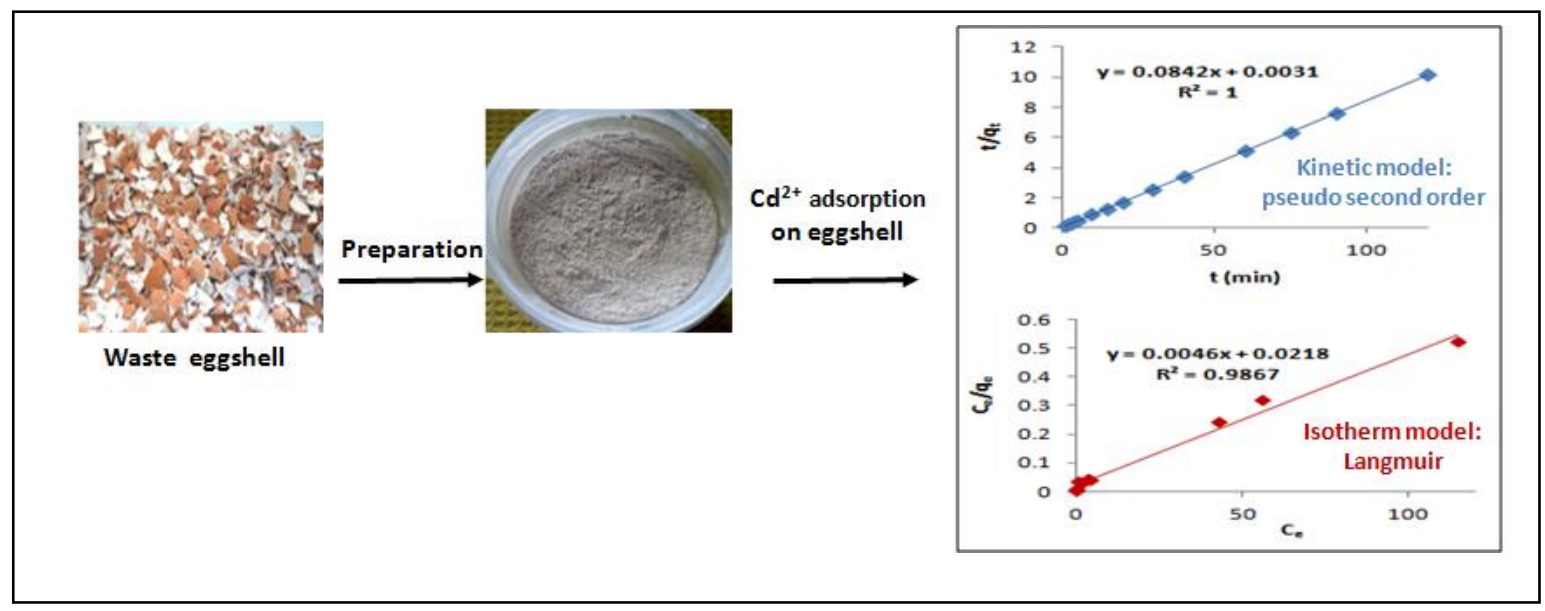




\section{Introduction}

Recently, heavy metals in water have become a global problem because most of them are toxic to organisms [1], non-degradable and accumulate in biota. Among these metals, cadmium is one of the most toxic and poses a significant risk to human health because, in excess, it causes serious diseases and many disorders [2,3]. The main sources of cadmium entering the environment come from wastewater discharged from many industrial sectors such as metal plating, $\mathrm{Cd}-\mathrm{Ni}$ batteries, stabilizers, pesticides, paints, pigments, plastics, metallurgy, textile printing industries and alloys [4,5].

Different methods have been used for cadmium removal, such as adsorption, ultrafiltration, coagulation, reverse osmosis, solvent extraction, electrodialysis, flocculation and membrane separation [6-9]. In most cases, these methods are very expensive and are only effective at high levels of metals present in aqueous solution [10]. Among them, the adsorption technique is an inexpensive conventional treatment technology, commonly used in the treatment of wastewater and the removal of heavy metals from the environment, due to its simplicity, short treatment time, ease of use, efficiency, and its ability to recycle the adsorbent and heavy metals $[\mathbf{1 1}, 12]$. The key factors determining the choice of a suitable adsorbent are sorption capacity, abundant local supply, low price and eco-friendly nature. Due to their metal sequestration properties, natural materials are ecologically relevant for reducing the concentration of heavy metals or dyes present in aqueous media, as demonstrated by the adsorption capacity of biosorbents materials, such as chicken eggshells [13-15], peanut shells [16], tea leaves [17], coffee husks [18], corncob [19] olive pomace [20] and olive seeds [21]. In particular, the use of eggshell is pertinent because it is an abundant waste produced by the food industry, economical and eco-friendly due to its availability and absence of any toxic and hazardous constituent's elements [11,22], and as efficient as the more expensive activated carbon [23]. This adsorbent is also used as a source of calcium for the synthesis of bioceramics [24], composites [25] and hydroxyapatite [26]. Several authors have shown that it is the calcium carbonate-based composition of chicken eggshells that has the property of adsorbing heavy metals, such as cadmium [27], chromium [10], nickel [28], lead [29], cobalt [30] and dyes [31,32]. The efficiency of biosorption processes depends on major factors such as initial metal ion concentration [33], contact time to saturation of active sites [34], temperature [35,36], $\mathrm{pH}[35]$ and biosorbent dose [37].

Extensive literature is available regarding the influence of the factors on process intensity by eggshells, however, the studies are difficult to compare because the effect of all the reaction parameters related to adsorption process of heavy metals are not available, and the mechanism 
of adsorption is not systematically investigated. Otun et al. [38] showed that maximum adsorption capacity of 4,7 and $17 \mathrm{mg}^{-\mathrm{g}^{-1}}$ can be reached for $\mathrm{Cd}(\mathrm{II}), \mathrm{Ni}(\mathrm{II})$ and $\mathrm{Pb}(\mathrm{II})$, respectively. A similar adsorption capacity of $3.75 \mathrm{mg} \cdot \mathrm{g}^{-1}$ for Cd(II) was also demonstrated by the work of Flores-Cano et al. [27], with a detailed description of the mechanism of adsorption by eggshells (diameter of $0.95 \mathrm{~mm}$ ). Another work by Ahmad et al. [39] showed that the sequence of metal sorption selectivity occurs in the following order: $\mathrm{Pb}^{2+}>\mathrm{Cu}^{2+}$ $>\mathrm{Cd}^{2+}$ with maximum amounts of metals adsorbed of $4.74,2.05$ and $0.5 \mathrm{mg} \cdot \mathrm{g}^{-1}$, respectively. In this work [39], two models of adsorption isotherms (Langmuir and Freundlich) were used for the mathematical description of the sorption equilibrium and the experimental data showed that the heavy metal adsorption isotherm with eggshell followed the Langmuir model. This work is therefore motivated by the desire to link the physico-chemical properties of eggshell waste and the influence of experimental conditions on its effective capacity to remove cadmium ions from aqueous solutions. To this end, the physico-chemical properties of the adsorbent are characterized by Brunauer-Emmett-Teller (BET) surface area measurement, Fourier transform infrared (FTIR) spectroscopy, scanning electron microscopy (SEM), thermogravimetric analysis (TGA) and X-ray diffraction (RXD). A systematic study of eggshell (ES) dose, $\mathrm{pH}$ and initial ion concentration and contact time is performed to show the influence of experimental conditions on the mechanism of cadmium ion adsorption and desorption kinetics.

\section{Materials and methods}

\subsection{Chemicals products}

Sodium chloride $(\mathrm{NaCl})$, nitric acid $\left(\mathrm{HNO}_{3}\right)$, hydrochloric acid $(\mathrm{HCl})$, sodium hydroxide $(\mathrm{NaOH})$, sulfuric acid $\left(\mathrm{H}_{2} \mathrm{SO}_{4}\right)$ and ethylenediaminetetraacetic acid (EDTA) of analytical grade were purchased from Sigma Aldrich Company. Cadmium nitrate tetrahydrate $\left(\mathrm{Cd}\left(\mathrm{NO}_{3}\right)_{2} \cdot 4 \mathrm{H}_{2} \mathrm{O}\right)$ was obtained from Merck. Deionized water was used in all experiments. The $\mathrm{pH}$ of the aqueous solutions was adjusted with $0.1 \mathrm{M}$ hydrochloric acid $(\mathrm{HCl})$ or sodium hydroxide $(\mathrm{NaOH})$.

\subsection{Preparation of eggshells as an adsorbent}

Eggshells (ES) were collected from household and kitchen waste. Before being used, they were washed several times with deionised water to remove impurities and pollutants, and then dried in an electric oven for $12 \mathrm{~h}$ at $70{ }^{\circ} \mathrm{C}$. Finally, the eggshells were crushed and sieved to 
obtain a powder of particles ranging in size from 200 to $1000 \mu \mathrm{m}$ and stored in sterilized containers for later use as an adsorbent (Fig.1A).

\subsection{Method for determining the $\mathrm{pH}$ point zero charge ( $\mathrm{pHpzc})$}

The $\mathrm{pH}$ with a total net particle load of zero is known as the zero point load (pHpzc), which is calculated to confirm the surface charge of the adsorbent and to identify the types of interaction between the binding sites of adsorbent and adsorbate molecules. The eggshell $\mathrm{pHzpc}$ was determined by the procedure described by Prahas et al. [40], by adding $0.05 \mathrm{~g}$ of adsorbent to a series of $\mathrm{NaCl}$ solutions $(50 \mathrm{~mL})$ of $0.1 \mathrm{~mol} . \mathrm{L}^{-1}$ for different $\mathrm{pH}$ values ranging from 2 to $12\left(\mathrm{pH}_{\text {initial }}\right)$. The $\mathrm{pH}$ of the suspension was adjusted using $0.1 \mathrm{M} \mathrm{HCl}$ or $\mathrm{NaOH}$ solutions and measured after stirring the solution at $150 \mathrm{rpm}$ for $24 \mathrm{~h}\left(\mathrm{pH}_{\text {final }}\right)$ at room temperature $\left(25^{\circ} \mathrm{C}\right)$.

The difference between the initial and final $\mathrm{pH}(\Delta \mathrm{pH})$ was plotted as a function of the initial $\mathrm{pH}$, and the pHpzc was obtained when the curve intersects the $\mathrm{x}$-axis. The $\mathrm{pH}_{\mathrm{pzc}}$ of eggshell was 9.27, meaning that its net surface charge becomes positive at $\mathrm{pH}$ below 9.27 and negative above that value.

\subsection{Characterization}

The morphology of eggshell particles was observed using scanning electron microscopy (SEM, HITACHI, S-530, ELKO Engineering). The identification of crystalline species present in eggshells was recorded by X-ray diffraction (XRD) analysis (Shidmazu). The specific surface area, volume and mean pore diameter of the eggshell particles were measured by the Brunauer-Emmett-Teller (BET) method using $77 \mathrm{~K}$ nitrogen with the Quantachrome instrument type. Thermal stability was studied by thermogravimetric analysis (TGA-2950 TA instrument). Studies by Fourier Transform Infrared Spectroscopy (FTIR, Thermo Nicolet 670 FTIR) were performed to identify functional groups on the surface of the eggshells.

Residual concentration of cadmium ions was measured by atomic absorption spectrophotometer (AAS) ( Model Thermo Fisher AAS 201).

\subsection{Adsorption experiments}

$\mathrm{Cd}^{2+}$ sorption experiments were carried out at $25{ }^{\circ} \mathrm{C}$ under magnetic stirring at $250 \mathrm{rpm}$ with various eggshell masses mixed with $25 \mathrm{~mL}$ of cadmium solution at different concentrations. The $\mathrm{pH}$ of the solutions was varied between 2.5 and 7 to avoid the precipitation of the cadmium ions, by adding $0.1 \mathrm{M}$ of $\mathrm{HCl}$ or $\mathrm{NaOH}$.

To determine the optimal mass of adsorbent, the ES dose was varied between 0.3 and 8 g. $\mathrm{L}^{-1}$. The initial cadmium concentration was studied in the range of 5 to $200 \mathrm{mg} . \mathrm{L}^{-1}$, similar to 
industrial practices, for a contact time varying from 1 to 120 min (longer times do not significantly improve the adsorption capacity). After time intervals from $1 \mathrm{~min}$ up to $120 \mathrm{~min}$, $0.5 \mathrm{~mL}$ of supernatant was analyzed by AAS to determine the residual concentration of $\mathrm{Cd}^{2+}$. The cadmium concentration was estimated from a calibration curve prepared with $\mathrm{Cd}^{2+}$ standard solutions.

The adsorption capacity $\mathrm{q}_{\mathrm{e}}\left(\mathrm{mg} \cdot \mathrm{g}^{-1}\right)$ at equilibrium and the percentage removal $\mathrm{R}(\%)$ of $\mathrm{Cd}^{2+}$ were determined by the following equations:

$$
\begin{aligned}
& q_{e}=\frac{C_{0}-C_{e}}{m} V \\
& R=\frac{C_{0}-C_{e}}{C_{0}} \times 100
\end{aligned}
$$

where $\mathrm{C}_{0}$ and $\mathrm{C}_{\mathrm{e}}\left(\mathrm{mg} \cdot \mathrm{L}^{-1}\right)$ are the initial and equilibrium concentrations of the metal cadmium, respectively, $\mathrm{V}(\mathrm{L})$ is the volume of solution, and $\mathrm{m}(\mathrm{g})$ is the weight of the adsorbent.

The data is a mean value resulting from experiments repeated three times for each experimental parameter.

\subsection{Adsorption kinetics and isotherm studies}

\subsubsection{Adsorption kinetics}

Kinetic modeling gives information about adsorption mechanisms and identifies the step limiting the process. In order to investigate the adsorption processes of $\mathrm{Cd}^{2+}$ on the eggshell, three kinetic models were applied.

(1) The pseudo-first order model, also known as the Lagergren equation [41], is described by the following formula:

$$
\log \left(q_{e}-q_{t}\right)=\log q_{e}-\frac{K_{1}}{2,3} t
$$

where $\mathrm{q}_{\mathrm{e}}$ and $\mathrm{q}_{\mathrm{t}}$ are the adsorption capacities at equilibrium in $\left(\mathrm{mg} \cdot \mathrm{g}^{-1}\right)$ at the time $\mathrm{t}$, and $\mathrm{K}_{1}$ is the rate constant adsorption for pseudo first order $\left(\mathrm{min}^{-1}\right)$.

This model assumes that adsorption takes place between one adsorbate molecule and one active site on the surface of the adsorbent. The kinetic parameters are calculated by the slope and intercept of $\log \left(\mathrm{q}_{\mathrm{e}}-\mathrm{q}_{\mathrm{t}}\right)$ as a function of the $\mathrm{t}$-curve. 
(2) In the pseudo-second order model $[\mathbf{4 2 , 4 3 ]}$, it is considered that one adsorbate molecule is adsorbed onto two active sites. A linear form of this kinetic model is presented as:

$$
\frac{t}{q_{t}}=\frac{1}{K_{2} q_{e}^{2}}+\frac{t}{q_{e}}
$$

With $\mathrm{K}_{2}$ is the constant of speed of pseudo-second order $\left(\mathrm{mg} \cdot \mathrm{g}^{-1} \cdot \mathrm{min}^{-1}\right)$. The $\mathrm{q}_{\mathrm{e}}$ and $\mathrm{K}_{2}$ values can be obtained from the slope and intercept of the linear plot $\left(t / q_{t}\right)$ against $t$.

(3) The intraparticle diffusion model describes the mass transfer of an adsorbate molecule to the outer surface of the adsorbent, and allows the determination of the adsorption rate and the diffusion mechanism [44]. It can be expressed as follows:

$$
q_{t}=K_{i} t^{\frac{1}{2}}+C
$$

where $K_{i}\left(m g \cdot g^{-1} \cdot m^{-1 / 2}\right)$ is the intra-particle diffusion rate constant, $q_{t}\left(m g \cdot g^{-1}\right)$ is the amount of metal ions adsorbed at time $\mathrm{t}$, and $\mathrm{C}\left(\mathrm{mg} \cdot \mathrm{g}^{-1}\right)$ is the intercept which represents a constant related to the thickness of the boundary layer.

A high adsorption rate can be attributed to an increased thickness of the boundary layer. The plot of the adsorption capacity $\left(\mathrm{q}_{\mathrm{t}}\right)$ versus the square root of adsorption time $\left(\mathrm{t}^{\frac{1}{2}}\right)$ allows the determination of the controlled adsorption process parameters.

\subsubsection{Adsorption isotherms}

The Langmuir adsorption isotherm model [45] has been applied to quantify the adsorption of $\mathrm{Cd}^{2+}$ on the eggshell. It reflects the adsorption of a monolayer of a target ion on a homogeneous surface, considering that all sites are equivalent and there is no interaction between the adsorbed ions. The generalized linear form of the Langmuir isotherm is represented by:

$$
\frac{C_{e}}{q_{e}}=\frac{1}{q_{m} K_{L}}+\frac{C_{e}}{q_{m}}
$$

Where $\mathrm{q}_{\mathrm{e}}$ is the amount adsorbed $\left(\mathrm{mg} \cdot \mathrm{g}^{-1}\right), \mathrm{C}_{\mathrm{e}}$ is the equilibrium solute concentration $\left(\mathrm{mg} . \mathrm{L}^{-1}\right)$, $\mathrm{q}_{\mathrm{m}}$ is the Langmuir constant associated with the adsorption capacity in (mg.g $\mathrm{g}^{-1}$ ), and $\mathrm{K}_{\mathrm{L}}$ is related to the energy of adsorption $\left(\mathrm{L}_{\mathrm{mg}} \mathrm{m}^{-1}\right.$ ). The values of $\mathrm{K}_{\mathrm{L}}$ and $\mathrm{q}_{\mathrm{m}}$ can be determined from the linear plot of $\frac{C_{e}}{q_{e}}$ versus $C_{e}$.

The Langmuir isotherm can be expressed by the dimensionless constant $\mathrm{R}_{\mathrm{L}}$ defined as [46]: 


$$
R_{L}=\frac{1}{1+K_{L} C_{i}}
$$

Where $K_{L}$ is the Langmuir constant and $C_{i}$ is the initial metal concentration $\left(m g \cdot L^{-1}\right), R_{L}$ value indicates the type of isotherm as irreversible $\left(\mathrm{R}_{\mathrm{L}}=0\right)$, favorable $\left(0<\mathrm{R}_{\mathrm{L}}<1\right)$, linear $\left(\mathrm{R}_{\mathrm{L}}=1\right)$ or unfavorable $\left(\mathrm{R}_{\mathrm{L}}>1\right)$.

The Freundlich isotherm is generally applied to the adsorption of multilayers, the model assumes a heterogeneous surface with a non-uniform distribution of heat of adsorption over the surface [47]. This linear form of this model can be given by:

$$
\operatorname{Ln} q_{e}=\operatorname{Ln} K_{f}+\frac{1}{n} \operatorname{Ln} C_{e}
$$

Where $K_{f}$ is the Freundlich adsorption capacity parameter $\left(\mathrm{L}_{\mathrm{g}} \mathrm{g}^{-1}\right.$ ) and $\mathrm{n}$ is a constant representing the adsorption intensity of the adsorbent. If $n=1$, the adsorption is linear; if $n$ $<1$, the adsorption is a chemical process; if $\mathrm{n}>1$, the adsorption is a physical process.

The plot of $\mathrm{Ln} \mathrm{q}_{\mathrm{e}}$ vs $\mathrm{Ln} \mathrm{C}_{\mathrm{e}}$ gives the Freundlich isotherm, where the slope is the value of 1/n and the intercept is equal to $\log \mathrm{K}_{\mathrm{f}}$. The Temkin isotherm equation assumes that the heat of adsorption of all the ions in the layer decreases linearly with coverage [48].

The linear form of the adsorption isotherm equation can be expressed as:

$$
q_{e}=B_{T} \ln K_{T}+B_{T} \ln C_{e}
$$

Where $B_{T}=\frac{R T}{b_{T}}$ with $\mathrm{T}$ is the absolute temperature and $\mathrm{R}$ is the gas constant $\left(\mathrm{R}=8.31 \mathrm{~J} . \mathrm{K}^{-}\right.$ $\left.{ }^{1} \mathrm{~mol}^{-1}\right), \mathrm{b}_{\mathrm{T}}$ is a constant related to the heat of adsorption $\left(\mathrm{J} \cdot \mathrm{mol}^{-1}\right)$ and $\mathrm{K}_{\mathrm{T}}$ is the equilibrium binding constant $\left(\mathrm{L}_{\mathrm{mg}} \mathrm{mg}^{-1}\right.$ ). A plot of $\mathrm{q}_{\mathrm{e}}$ versus $\operatorname{lnC}_{\mathrm{e}}$ enables the determination of the isotherm constants $\mathrm{K}_{\mathrm{T}}$ and $\mathrm{B}_{1}$.

\section{Results and discussion}

\subsection{Characterization of ES}

The eggshell, prepared according to the procedure described in Fig. 1(a), presents a relatively smooth surface with a flake-like appearance, as shown by SEM images (Fig. 1(b)). Higher SEM magnifications show the presence of irregular structures with a heterogeneous particle 
size distribution between 86 and $292 \mu \mathrm{m}$, and a porous morphology which is responsible for the adsorption of metals ions.

Further studies by XRD, FT-IR and TGA were performed to gain more insights about the eggshell structure. The crystallinity of the ES adsorbent was characterized by XRD. Fig. 2(a) shows the presence of a main peak at $2 \theta=29.7^{\circ}$, and smaller peaks at $2 \theta=23.26^{\circ} ; 36.3^{\circ}$; $39.8^{\circ} ; 43.6^{\circ} ; 47.9^{\circ} ; 48.9^{\circ} ; 57.8^{\circ}$ and $65.8^{\circ}$, which confirm the presence of calcite in the eggshell structure. Calcite is the most thermodynamically stable form of calcium carbonate $\left(\mathrm{CaCO}_{3}\right)$ at room temperature [49], reflecting the high hardness of the eggshell and its rhombohedral structure [50]. This diffractogram confirms that the compound is pure and crystalline.

Fig. 2(b) shows the FTIR spectra of eggshell powder with numerous bands between $4000 \mathrm{~cm}^{-1}$ to $400 \mathrm{~cm}^{-1}$. Examination of the graph shows that a significant absorption peak of the carbonate mineral is present at $1401 \mathrm{~cm}^{-1}$. The two other peaks observed at 713 and $875 \mathrm{~cm}^{-1}$ corresponding to $\mathrm{Ca}-\mathrm{O}$ and $\mathrm{C}-\mathrm{O}$, respectively, are associated with the deformation vibration in the plane of $\mathrm{CaCO}_{3}$. The position of the peak at $1616 \mathrm{~cm}^{-1}$ corresponds to the $\mathrm{N}-\mathrm{H}$ of the residual proteins and amino acids of the eggshell and eggshell membrane, and the characteristic $\mathrm{O}-\mathrm{H}$ peak at $3401 \mathrm{~cm}^{-1}$ results mainly from the absorption of moisture and water molecules during the eggshell preparation procedure.

The surface properties of the eggshell adsorbent was studied by nitrogen adsorptiondesorption isotherms. This technique allows the assessment of the textural properties of porous materials by using $\mathrm{N}_{2}$ as a probing molecule. Quantitative data are reported in Table 1 . The estimated BET surface area is $2.35 \mathrm{~m}^{2} \cdot \mathrm{g}^{-1}$. This value is higher than the literature values of $0.07-2 \mathrm{~m}^{2} \cdot \mathrm{g}^{-1}[\mathbf{2 7}, \mathbf{5 1 - 5 3}]$.

The profile of TGA of the natural eggshell is shown in Fig. 2(c). The graph shows a weight loss of $3.54 \%$ below $200{ }^{\circ} \mathrm{C}$, attributed to the loss of physically absorbed water. The degradation step at temperatures between $200{ }^{\circ} \mathrm{C}$ and $600{ }^{\circ} \mathrm{C}$ corresponds to the decomposition of organic matter of the eggshell. The significant mass loss of $41.23 \%$ around 600-800 ${ }^{\circ} \mathrm{C}$ is attributed to the decarboxylation of $\mathrm{CaCO}_{3}$ linked to the release of carbon dioxide $\mathrm{CO}_{2}$ and thus the formation of $\mathrm{CaO}$ at this temperature [54]. After $800^{\circ} \mathrm{C}$, the material tends to be stable up to $1000{ }^{\circ} \mathrm{C}$. The weight of the sample decreases when it is converted to $\mathrm{CaO}$ and gas phase of $\mathrm{CO}_{2}$. 


\subsection{Optimization of biosorption process}

Then, the biosorption process of Cd(II) ions on eggshells was optimized according to the following physico-chemical parameters: the adsorbent dose, the initial $\mathrm{pH}$, the concentration of cadmium and the contact time until saturation of the active sites.

\subsubsection{Effect of adsorbent dose and $\mathrm{pH}$}

The percentage removal of cadmium ions was studied by varying the adsorbent dose in the range of 0.3 to $8 \mathrm{~g} . \mathrm{L}^{-1}$ for an adsorption experiment fixed to $120 \mathrm{~min}$ at $\mathrm{pH}$ 5.5. In Fig. 3(a), the result shows that the percentage of $\mathrm{Cd}^{2+}$ increases from 92.4 to $99.9 \%$ when the amount of eggshell increased from 0.3 to 8 g. $\mathrm{L}^{-1}$, with the maximum removal of $\mathrm{Cd}^{2+}$ reached from of 2 g. $\mathrm{L}^{-1}$ of ES.

Fig. 3(b) shows the effect of $\mathrm{pH}$ of the $\mathrm{Cd}^{2+}$ solution on the percentage removal of the ions. The $\mathrm{pH}$ was limited to the range 2.5-7 due to the precipitation of cadmium(II) hydroxide $\left(\mathrm{Cd}(\mathrm{OH})_{2}\right)$ at higher $\mathrm{pH}[55]$. The results show that the adsorption capacity of the eggshell sorbent increases significantly as the $\mathrm{pH}$ increases, with a maximum removal of $99 \%$ between pH 5-7.

Based on the above screenings, the experimental conditions of eggshell dose $=0.8 \mathrm{~g} . \mathrm{L}^{-1}$ and $\mathrm{pH}=5$ were chosen as the best compromise for further investigations.

\subsubsection{Effect of contact time}

The impact of the contact time between the ES and the $\mathrm{Cd}^{2+}$ solution on the efficiency of the $\mathrm{Cd}^{2+}$ removal was also carefully studied. Fig. 3(c) shows that the amount of $\mathrm{Cd}^{2+}$ removed increases to $99 \%$ after $10 \mathrm{~min}$ for the adsorbent dose of $0.8 \mathrm{mg} . \mathrm{L}^{-1}$. The rapid adsorption of the ions is due to the number and availability of vacant active sites on the surface of the ES. The contact time of $10 \mathrm{~min}$ has a beneficial effect in reducing the cost of operation, and was therefore chosen as the optimal contact time for the next step.

\subsubsection{Effect of initial Cd(II) ions concentration}

As a critical parameter, the effect of initial Cd(II) ions concentration in the range 5-200 mg. $\mathrm{L}^{-}$ 1 on the adsorption efficiency on ES adsorbent was studied. To this end, in Fig. 3(d), the percentage removal $\mathrm{R}(\%)$ of $\mathrm{Cd}^{2+}$ and the adsorption capacity $\mathrm{q}_{\mathrm{e}}\left(\mathrm{mg} \cdot \mathrm{g}^{-1}\right)$ at equilibrium versus the initial concentration of $\mathrm{Cd}^{2+}$ were presented. The experimental conditions consisted in eggshell amount of $0.8 \mathrm{~g} . \mathrm{L}^{-1}$, initial $\mathrm{pH}=5$ and a contact time of $10 \mathrm{~min}$.

The results show that an increase in the initial metal concentration results, on the one hand, in a gradual increase in adsorption capacity and, on the other hand, a sudden decrease in the removal percentage from $99.5 \%$ to $60 \%$ for initial cadmium concentrations above $100 \mathrm{mg} . \mathrm{L}^{-}$ 
1. The progressive increase of the adsorption capacity is related to the driving force, i.e. a concentration gradient that develops between the solution and the adsorbent, as well as to an increased probability of interactions between the sorbent and the cadmium ions [56]. The decrease in the adsorption percentage with increasing concentration can be attributed to the saturation of sorption sites of the adsorbent, as the surface area is not large enough to adsorb a much larger amount of available metal ions from the solution. Similar results were reported for adsorption of nickel onto eggshell [57] and reactive red dye onto eggshell composite [31].

\subsection{Adsorption kinetic modeling}

Kinetic modeling gives information about adsorption mechanisms and identifies the step limiting the process. In order to investigate the adsorption processes of cadmium ions on the eggshell, three kinetic models of pseudo-first, pseudo-second order (linear or non-linear forms) and intraparticle diffusion were applied and the kinetic equations in their linearized forms are presented in Table 2.

From Fig. 4 and Table 2, the pseudo second order model best describes the experimental adsorption data with a higher correlation coefficient $\left(\mathrm{R}^{2}=1\right)$ compared to the pseudo first order equation $\left(\mathrm{R}^{2}=0.93\right)$, and a theoretical experimental values of $\mathrm{q}_{\mathrm{e}}\left(11.87 \mathrm{mg} \cdot \mathrm{g}^{-1}\right)$ close to the experimental value (11.86 mg. $\mathrm{g}^{-1}$, determined from $\mathrm{q}_{\mathrm{t}}$ versus $\mathrm{t}$ in Fig. 3(c)).

The intraparticle diffusion rate can also control the adsorption of $\mathrm{Cd}^{2+}$ to the surface of the eggshell. According to Fig. 4(c), the curve of $\mathrm{q}_{\mathrm{t}}$ versus $\mathrm{t}^{0.5}$ is non-linear and does not pass through the origin. It can therefore be concluded that the intraparticle diffusion can be divided into two distinct linear regions. The first linear region corresponds to the transfer of the metal ion from the solution to the outer surface of the ES. The high initial rate of cadmium removal is due to strong electrostatic attraction and active adsorption sites, with $\mathrm{Cd}(\mathrm{II})$ diffusing into the pores of the adsorbent. This step represents intraparticle diffusion or diffusion into the pores. The second step indicates that the ions adsorption process has gradually reached the final equilibrium between the solution and the adsorbent. A similar mechanism has been reported by Manirethan et al. [58] for the removal of $\mathrm{Hg}(\mathrm{II}), \mathrm{Cr}(\mathrm{VI}), \mathrm{Pb}(\mathrm{II})$ and $\mathrm{Cu}$ (II) ions from an aqueous solution by a biosynthesized melanin adsorbent.

Les résultats suggèrent que le mécanisme d'adsorption du pseudo-second ordre est prédominant, ce modèle étant basé sur l'hypothèse que la vitesse d'adsorption est contrôlée par l'adsorption chimique [59-60], qui inclut l'interaction entre l'adsorbant et l'adsorbat (ion 
métallique) [43,61]. La chimisorption joue donc un rôle important dans le mécanisme d'adsorption du Cd(II) par échange d'ions sur la coquille d'œuf. Le mécanisme est favorisé par la similitude du rayon des ions, ce qui entraîne l'échange d'ions $\mathrm{Ca}^{2+}(0,099 \mathrm{~nm})$ par des ions $\mathrm{Cd}^{2+}(0,097 \mathrm{~nm})$ à la surface de la calcite (Fig.5), selon la réaction chimique suivante $[59,62]$ :

$$
\mathrm{CaCO}_{3(\mathrm{~s})}+\mathrm{Cd}^{2+} \longleftrightarrow \mathrm{CdCO}_{3(\mathrm{~s})}+\mathrm{Ca}^{2+}
$$

\subsubsection{Sorption isotherm model}

The isotherm study is an important analysis to identify the adsorption performance and describe the relationship between solute and adsorbent. To this end, the $\mathrm{Cd}^{2+}$ adsorption on eggshell adsorbent was next studied using Langmuir, Freundlich and Timkin models in Fig. 6. The resulting isotherm parameters are reported in Table3.

According to the analysis of the regression coefficients $\left(\mathrm{R}^{2}\right)$, the Langmuir model has the highest value $\left(\mathrm{R}^{2}=0.986\right)$ compared to those obtained from the Feundlich and Timkin isotherm models, and is favourable to the chemical adsorption of a homogeneous monolayer of $\mathrm{Cd}^{2+}$ on the surface of eggshell adsorbent. The theoretical maximum metal adsorption capacity $\mathrm{q}_{\mathrm{m}}$ of $217.4 \mathrm{mg} . \mathrm{g}^{-1}$ (obtained from the theoretical slope) is in good agreement with the experimental maximal value of $221.25 \mathrm{mg} \cdot \mathrm{g}^{-1}$, deduced from the plot $\mathrm{q}_{\mathrm{e}}=\mathrm{f}\left(\mathrm{C}_{\mathrm{e}}\right)$ (not shown). In addition, the $\mathrm{R}_{\mathrm{L}}$ value is in the range of $0<\mathrm{R}_{\mathrm{L}}<1$, indicating that adsorption of the $\mathrm{Cd}^{2+}$ is promoted on ES.

The Freundlich parameters obtained in this work are $K_{f}=36.49 \mathrm{~L}_{\mathrm{f}} \mathrm{g}^{-1}$ and $\mathrm{n}=2.43$. The value of $1 / \mathrm{n}$ obtained is between 0 and 1 , indicating that the adsorption of $\mathrm{Cd}^{2+}$ on eggshell is favorable. Since the value of $\mathrm{R}^{2}$ in Temkin isotherm model is lower than the Langmuir and Freundlich isotherms, it can be assumed that this isotherm is not suitable for use as a model for predicting the cadmium adsorption isotherms studied on the eggshell.

\subsection{Comparison of adsorption capacity for cadmium with other adsorbents}

A comparison of adsorption capacity of ES with other adsorbents reported in literature for the removal of $\mathrm{Cd}^{2+}$ is presented in Table 4. Although direct comparison of the removal capacity of different adsorbents is not straightforward due to the diversity of experimental conditions, the result indicates that the adsorption capacity of $\mathrm{Cd}^{+2}$ in this study is higher than that of most of the adsorbents listed in Table 4. This performance can be attributed to its higher 
specific surface area $\left(2.35 \mathrm{mg} \cdot \mathrm{g}^{-1}\right.$ ) compared to other works (such as $0.07 \mathrm{mg} . \mathrm{g}^{-1}$ [27] and $1.71 \mathrm{mg} . \mathrm{g}^{-1}$ [63]), which could be related to the origin of the eggs, and to the particle size, which is dependent on the heat treatment as well as the grinding and sieving method. It was concluded that ES with a relatively high adsorption capacity could be used as an alternative material to remove cadmium ions from an aqueous solution, considering the low cost of this natural adsorbent.

\subsection{Desorption Studies}

One of the important characteristics of an adsorbent is its ability to be regenerated. In this work, four different eluents such as $\mathrm{NaOH}, \mathrm{HCl}, \mathrm{H}_{2} \mathrm{SO}_{4}, \mathrm{HNO}_{3}$ and EDTA were tested for the desorption of cadmium ions. $\mathrm{HNO}_{3}$ was found to be the most effective, desorbing $96 \%$ of this metal as shown in Fig.7.

The ability of desorption was calculated by the following equation:

$$
\% \text { of desorption }=\frac{q_{d}}{q_{a}} \times 100
$$

Where $\mathrm{q}_{\mathrm{d}}$ is amount of metal ions desorbed (mg. $\mathrm{g}^{-1}$ ) and $\mathrm{q}_{\mathrm{a}}$ is adsorption capacity of metal ions adsorbed on the eggshell (mg.g $\left.{ }^{-1}\right)$.

The effect of $\mathrm{HNO}_{3}$ concentration on desorption efficiency of cadmium showed that the desorption efficiency of this metal increased with the concentration of $\mathrm{HNO}_{3}$ solution, and the maximum percentage recovery of $\mathrm{Cd}$ was $96 \%$ with $0.1 \mathrm{M} \mathrm{HNO}_{3}$ solution (result not shown). This high percentage of $\mathrm{Cd}^{2+}$ desorption has been attributed to more repulsive electrostatic interactions between the ions and the active sites of the protonated adsorbent in the presence of $\mathrm{HNO}_{3}$.

\section{Conclusion}

The present work was aimed to provide a complete understanding of the effect of the physicochemical properties of eggshell waste and the influence of experimental conditions on the removal of $\mathrm{Cd}^{2+}$ from aqueous solutions.

Different physicochemical methods (BET, TGA, FTIR, XRD, SEM) were integrated to characterize the physico-chemical properties of the adsorbent and to interrogate the propertyto-performance relationship. The outcomes show that experimental conditions such as eggshell (ES) dose, $\mathrm{pH}$, initial ion concentration and contact time affect at different levels the efficiency of eggshell waste as a bioadsorbent to remove $\mathrm{Cd}^{2+}$ from aqueous solutions.

The results suggest that the removal of $\mathrm{Cd}^{2+}$ proceeds via a chemical adsorption mechanism described by a pseudo-second order model, in good agreement with the 
experimental data, and follows the sorption isotherm model of Langmuir. The adsorption process is rapid and reached equilibrium within $10 \mathrm{~min}$ at $\mathrm{pH} \mathrm{5}$, with an initial metal concentration of $10 \mathrm{mg} . \mathrm{L}^{-1}$, and an adsorbent dose of $0.8 \mathrm{~g} . \mathrm{L}^{-1}$. To date, the maximum adsorption capacity of $217.4 \mathrm{mg} \cdot \mathrm{g}^{-1}$ is higher than similar sorbents reported in the literature and it is mainly attributed to the high specific surface area of eggshell powder used in this work. Besides, it is shown that $\mathrm{HNO}_{3}$ has been successfully used for the desorption of cadmium ions from ES powder. The present study contributes to advances in the use of eggshell, as an efficient and low cost material, offering high removal efficiency, fast kinetics and environmentally friendly method for the removal of cadmium from wastewaters.

\section{Declaration of Competing Interest}

The authors declare that they have no known competing financial interests or personal relationships that could have influenced the work reported in this paper.

\section{Acknowledgements}

We thank Didier Cot, Arie van der Lee, Nathalie Masquelez, Abdeslam el Manssouri and Valérie Bonniol from IEM Montpellier for assistance during SEM, XRD, TGA, BET and AAS measurements.

\section{References}

[1] P.A. Alaba, Y.M. Sani, S.F. Olupinla, W.M.W. Daud, I.Y. Mohammed, C.C. Enweremadu, O.O. Ayodele, Toward N-nitrosamines free water: formation, prevention and removal, Crit Rev. Environ. Sci. Technol. 47(24) (2017) 2448-2489

[2] Y.Zang, B. Devleesschauwer, P.M. Bolger, E. Goodman, H.J. Gibb, Global burden of late stage chronic kidney disease resulting from dietary exposure to cadmium 2015, Environ. Res. 169(2018)72-78.

[3] G. F. Nordberg, Historical perspectives on cadmium toxicology, Toxicol. Appl. Pharmacol. 238(3)(2009) 192-200.

[4] L. Chen, L. Lu, W. Shao, F. Luo, Kinetics and equilibrium of Cd(II) adsorption onto a chemically modified lawny grass with [HBTMPP], J. Chem. Eng. Data. 56(2011)1059-1068. 
[5] Q.Tang, X.Tang, M. Hu, Z. Li, Y. Chen, P.J. Lou, Removal of Cd(II) from aqueous solution with activated Firmiana Simplex Leaf: behaviors and affecting factors, J.Hazard. Mater 179(2010)95-103.

[6] J.L. Hu, X.W. He, C.R. Wang, J.W. Li, C.H. Zhang, Cadmium adsorption characteristic of alkali modified sewage sludge, Biores. Technol. 121(2012)25-30.

[7] R.Molinari, S.Gallo, P.Argurio, Metal ions removal from wastewater or washing water from contaminated soil by ultrafiltration-complexation, Water. Res. 38(2004)593-600.

[8] M. Bilal, T.G. Kazi, H.I. Afridi, M.B. Arain, N. Khan, Application of conventional and modified cloud point extraction for simultaneous enrichment of cadmium, lead and copper in lake water and fish muscles, J. Ind. Eng. Chem. 40(2016)137-144.

[9] A. Mittal, M.Teotia, R.K. Soni, J. Mittal, Applications of egg shell and egg shell membrane as adsorbents: A review, J. Mol. Liq. 223(2016) 376-387.

[10] J. Wang, C. Chen, Biosorption of heavy metals by saccharomyces cerevisiae: A review, Biotechnol. Adv. 24(2006)427-451.

[11] P. Musonge, C. Harripersadth, The applicability of eggshell waste as a sustainable biosorbent medium in wastewater treatment - A Review, Adv in Wastewater Treat.91 (2021) 171- 203.

[12] P.A. Alaba, N.A. Oladoja, Y.M. Sani, O.B. Ayodele, I.Y. Mohammed, S.F. Olupinla, W.M.W. Daud, Insight into wastewater decontamination using polymeric adsorbents, J. Environ. Chem. Eng. 6(2) (2018) 1651-1672.

[13] A. Rajendran, C. Mansiya, Extraction of chromium from tannery effluents using waste eggshell material as an adsorbent, Br. J. Environ. Clim. Chang. 11(2011) 44-52.

[14] N.A. Rohaizar, N.A. Hadi, W.C. Sien, Removal of $\mathrm{Cu}(\mathrm{II})$ from water by adsorption on chicken eggshell, Int. J. Eng. Technol. 13(2013)40-45. 
[15] H. Daraei, A. Mittal, M. Noorisepehr, J. Mittal, Separation of chromium from water samples using eggshell powder as a low-cost sorbent: kinetic and thermodynamic studies, Desalin.Water Treat. 53 (2013) 1-7.

[16] W. Krowiak, R. Szafran, S. Modelski, Biosorption of heavy metals from aqueous solutions onto peanut shell as alow-cost biosorbent, Desalination 265 (2011)-126-134.

[17] S.S. Ahluwalia, D.Goyal, Removal of heavy metals by waste tea leaves from aqueous solution, Eng. Life Sci. 5 (2005) 158-162.

[18] L. Oliveira, A.S. Franca, T.M. Alves, S.D.F. Rocha,. Evaluation of untreated coffee husks as potential biosorbents for treatment of dye contaminated waters, J. Hazard. Mater 155 (2008) 507-512.

[19] R. Leyva-Ramos, L.E. Landin-Rodriguez, S. Leyva-Ramos, N.A. Medellin-Castillo, Modification of corncob with citric acid to enhance its capacity for adsorbing cadmium(II) from water solution, Chem. Eng. J. 180 (2012) 113-120.

[20] F. Pagnanelli, C. Cruz-Viggi, L. Toro,. Development of new composite biosorbents from olive pomace wastes, Appl. Surf. Sci. 256(2010)5492-5497.

[21] O. Agboola, B. Okoli, S.E. Sanni, P.A. Alaba, P. Popoola, ER. Sadiku, P.M. Mubiayi, E.T. Akinlabi, M.E. Makhatha, Synthesis of activated carbon from olive seeds: investigating the yield, energy efficiency, and dye removal capacity, SN. Appl. Sci. 1(1) (2019)85

[22] H. Faridi, A. Arabhosseini, Application of eggshell wastes as valuable and utilizable products: A review, Res. Agr. Eng. 64 (2018) 104-114

[23] W. Tsai, J. Yang, C. Lai, Y. Cheng, C. Lin, C. W. Yeh, Characterization and adsorption properties of eggshells and eggshell membrane, Bioresour. Technol. 97 (2006) 488-493.

[24] S.J. Lee, S.H. Oh, Fabrication of calcium phosphate bioceramics by using eggshell and phosphoric acid, Mater. Lett. 57 (2003) 4570-4574. 
[25] P. Toro, R.Quijada, M.Yazdani-Pedram, J.L. Arias, Eggshell, a new bio-filler for polypropylene composites, Mater. Lett. 61 (2007) 4347-4350.

[26] H. Khandelwal1, S. Prakash, Synthesis and characterization of hydroxyapatite powder by eggshell, J. Miner. Mater. Charact. Eng. 4 (2016) 119-126.

[27] J. V. Flores-Canoa, R. Leyva-Ramosa, J. Mendoza-Barrona, R.M. Guerrero-Coronadoa, A. Aragón-Pĩnab, G.J. Labrada-Delgado, Sorption mechanism of Cd(II) from water solution onto chicken eggshell, Appl. Surf. Sci. 276 (2013) 682-690.

[28] O. Khelifi, M. Nacef, A.M. Affoune, Biosorption of Nickel(II) ions from aqueous solutions by using Chicken eggshells as low-cost biosorbent, Algerian J. Environ. Sci. Technol. 2 (2016) 2437-1114.

[29] C. Arunlertaree, W. Kaewsomboon, A. Kumsopa, P. Pokethitiyook, P. Panyawathanakit, Removal of lead from battery manufacturing wastewater by eggshell, Songklanakarin J. Sci. Technol. 29 (2007) 857-868.

[30] S. Mignardi, L. Archilletti, L. Medeghini, C.D. Vito, Valorization of Eggshell Biowaste for Sustainable Environmental Remediation, Scientific Reports (2020) 10:2436.

[31] M.F. Elkady, A.M. Ibrahim,. M.M. Abd El-Latif, Assessment of the adsorption kinetics, equilibrium and thermodynamic for the potential removal of reactive red dye using eggshell biocomposite beads, Desalination 278 (2011) 412-423.

[32] A.S. Yusuff, Adsorption of cationic dye from aqueous solution using composite chicken eggshell anthill clay: optimization of adsorbent preparation conditions, Acta Polytechnica 59 (2019) 192-202.

[33] I. S. Okure, P. C. Okafore, U. J. Ibok, Adsorption of $\mathrm{Cu}^{2+}, \mathrm{As}^{3+}$ and $\mathrm{Cd}^{2+}$ ions from aqueous solution by eggshell, Glob. J. Pure Appl. 16 (2010) 407- 416.

[34] M. Kanyal, A.A. Bhatt, Removal of Heavy Metals from Water $(\mathrm{Cu}$ and $\mathrm{Pb})$ Using Household Waste as an Adsorbent, J. Bioremed. Biodeg. 6 (2015) 269. 
[35] K. Chojnacka, Biosorption of $\mathrm{Cr}$ (III) ions by eggshells, J. Hazard. Mater B. 121(2005)167-173.

[36] N. Yeddou, A. Bensmaili, Equilibrium and kinetic modeling of iron adsorption by eggshells in a batch system: effect of temperature, Desalination 206(2007)127-134.

[37] A.S. Yusuff, I.I. Olateju, S.E. Ekanem, Equilibrium, Kinetic and Thermodynamic Studies of the Adsorption of Heavy Metals from Aqueous Solution by Thermally Treated Quail Eggshell, J. Environ. Sci. Technol. 10(5)(2017)245-257.

[38] J.A. Otun, I.A. Oke, N.O. Olarinoye, D.B. Adie, C.A. Okuofu, Adsorption isotherms of $\mathrm{Pb}(\mathrm{II}), \mathrm{Ni}(\mathrm{II})$ and Cd(II) ions onto PES, J. Appl. Polym. Sci. 6 (11) (2006)2368-2376.

[39] M. Ahmad, A.R.A. Usman, S.S. Lee, S.C. Kim, J.H. Joo, J.E. Yang, Y.S. Ok, Eggshell and coral wastes as low cost sorbents for removal of $\mathrm{Pb}^{2+}, \mathrm{Cd}^{2+}$ and $\mathrm{Cu}^{2+}$ from aqueous solutions, J.ind. Eng. Chem. 18(2012)198-204.

[40] D. Prahas, Y. Kartika, N. Indraswati, S. Ismadji, Activated carbon from jackfruit peel waste by $\mathrm{H} 3 \mathrm{PO} 4$ chemical activation: pore structure and surface chemistry characterization, Chem. Eng. J. 140(2008)32-42.

[41] S. Lagergren, About the theory of so-called adsorption of soluble substances, K. Sven.Vetenskapsakad. Handl. 24 (4)(1898) 1-39.

[42] Y.S. Ho, G. Mckay, Sorption of dye from aqueous solution by peat, Chem. Eng. J.70, (1998)115-124.

[43] Y.S. Ho, G. McKay, Pseudo-second order model for sorption processes, Process Biochem. 34(1999)451-465.

[44] W.J. Weber, J.C. Morris, Kinetics of adsorption of carbon from solution, J. Sanit. Eng. Div. 89(1)( 1963)31-60. 
[45] I. Langmuir, The adsorption of gases on plane surface of glass, mica and platinum, J. Am. Chem. Soc. 40(1918)1361-1403.

[46] M. Riaz, R. Nadeem, M.A. Hanif, T.M. Ansari, K. Rehman, Pb(II) biosorption from hazardous aqueous streams using Gossypium hirsutum (Cotton) waste biomass, J. Hazard. Mater 161(2009)88-94.

[47] H.M.F. Freundlich, Over the adsorption in solution, J. Phys. Chem. 57(1906)385-471.

[48] M. Temkin, V. Pyzhev, Recent modifications to Langmuir Isotherms, Acta Physiochim USSR 12(1940)217-222.

[49] C.S. Gopinath, S.G. Hegde, A.V. Ramaswany, S. Mahapatra, Photoemission studies of polymorphic $\mathrm{CaCO}_{3}$ materials, Mater. Res. Bull. 37(2002)1323-1332.

[50] T. Zaman, M.M. Mostari, A.A. Mahmood, M.S. Rahman, Evolution and characterization of eggshell as a potential candidate of raw material, Cerâmica 64(2018)236-241.

[51] W.T Tsai, J.M. Yang, H.C. Hsu, C.M. Lin, K.Y. Lin, C.H. Chiu, Development and characterization of mesoporosity in eggshell ground by planetary ball milling, Micropor Mesopor Mat 111(2008)379-386.

[52] F. Granados-Correa, M. Jiménez-Reyes, Equilibrium and thermodynamic studies on the adsorption of $\mathrm{Eu}$ (III) by eggshell from aqueous solutions, Adsorp Sci Technol. 31(10)(2013)891-902.

[53] A.F. Santos, A.L. Arim, D.V. Lopes, L.M. Gando-Ferreira, M.J. Quina, Recovery of phosphate from aqueous solutions using calcined eggshell as an eco-friendly adsorbent, J. Environ. Manage. 238(2019)451-459.

[54] P. Khemthong, C. Luadthong, W. Nualpaeng, P. Changsuwan, P. Tongprem, N. Viriyaempikul, Industrial eggshell wastes as the heterogeneous catalysts for microwave-assisted biodiesel production, Catal. Today 190(2012)112-116. 
[55] G.A. Adebisi, Z.Z. Chowdhury, and P.A. Alaba, Equilibrium, kinetic, and thermodynamic studies of lead ion and zinc ion adsorption from aqueous solution onto activated carbon prepared from palm oil mill effluent. J. Clean. Prod. 148 (2017) 958-968.

[56] P. Sathishkumar, M. Arulkumar, T. Palvannan, Utilization of agro-industrial waste Jatropha curcas pods as an activated carbon for the adsorption of reactive dye Remazol Brilliant Blue R (RBBR), J. Clean. Prod. 22 (1)(2012)67-75.

[57] H. Kristianto, N. Daulay, A.A. Arie, Adsorption of Ni(II) Ion onto Calcined Eggshells: A Study of Equilibrium Adsorption Isotherm, Indones. J. Chem. 19 (1)(2019)143-150.

[58] V. Manirethan, K. Raval, R. Rajan, H. Thaira, R.M. Balakrishnan, Kinetic and thermodynamic studies on the adsorption of heavy metals from aqueous solution by melanin nanopigment obtained from marine source: Pseudomonas stutzeri, J. Environ. Manag. 214, (2018)315-324.

[59] S.S. Gupta, K.G. Bhattacharyya, Kinetics of adsorption of metal ions on inorganic materials: A review, Adv. Colloid Interface Sci. 162(2011)39-58.

[60] E. Igberase, P. Osifo, Equilibrium, kinetic, thermodynamic and desorption studies of cadmium and lead by polyaniline grafted cross-linked chitosan beads from aqueous solution, J. Ind. Eng. Chem. 26(2015)340-347.

[61] S. Lu, S.W. Gibb, Copper removal from wastewater using spent-grain as biosorbent. Bioresour, Technol. 99(2008)1509-1517.

[62] J.M. Zachara, C.E. Cowan, C.T. Resch, Metal cation/anion adsorption calcium carbonate: implications to metal ion concentrations in groundwater. In: Metals in Groundwater (ed. M. P. H. Allen, D. Brown), Chelsea, MI: Lewis Publishers, 1993, pp. 3771.

[63] C. Harripersadth, P. Musonge, Y.M. Isaa, M.G. Moralesb, A.Sayago, The application of eggshells and sugarcane bagasse as potential biomaterials in the removal of heavy metals from aqueous solutions, S. Afr. J. Chem. Eng. 34 (2020) 142-150 
[64] C. Jeon, Adsorption behavior of cadmium ions from aqueous solution using pen shells, J. Ind. Eng. Chem. 58(2018) 57-63.

[65] M. Torab-Mostaedi, M. Asadollahzadeh, A. Hemmati, A. Khosravi, Equilibrium, kinetic, and thermodynamic studies forbiosorption of cadmium and nickel on grapefruit peel, J.Taiwan Inst.Chem. Eng. 44(2013)295-302.

[66] J.R. Memon, S.Q. Memon, M.I. Bhanger, G.Z. Memon, A. El-Turki, G.C. Allen, Characterization of banana peel by scanning electron microscopy and FT-IR spectroscopy and its use for cadmium removal, Colloids Surf B. 66(2008)260-265.

[67] V.O. Njoku, A.A. Ayuk, E.E. Oguzie, E.N. Ejike, Biosorption of Cd(II) from aqueous solution by cocoa pod husk biomass: equilibrium, kinetic, and thermodynamic studies, Sep. Sci.Technol. 47(2012)753-761.

[68] U. Garg, M.P. Kaur, G.K.Jawa, D.Sud, V.K. Garg, Removal of cadmium (II) from aqueous solutions by adsorption on agricultural waste biomass, J. Hazard. Mater. 154(2008) $1149-1157$.

[69] M. Basu, A.K. Guha, L. Ray, Adsorption behavior of cadmium on husk of lentil. Process, Saf. Environ. Prot. 106(2017)11-22.

[70] E. Pehlivan, B.H. Yanik, G. Ahmetli, M. Pehlivan, Equilibrium isotherm studies for the uptake of cadmium and lead ions onto sugar beet pulp, Bioresour.Technol.99(2008)3520 3527.

[71] A. Taiwo, N. Chinyere, Sorption characteristics for multiple adsorption of heavy metal ions using activated carbon from nigerian bamboo, J. Mater. Sci. Chem. Eng 4(2016)39-48.

[72] J. R. Rangel-Mendez, R. Monroy-Zeped, E. Leyva-Ramos, P. E. Diaz-Flores, K. Shirai, Chitosan selectivity for removing cadmium(II), copper(II), and lead(II) from aqueous phase: pH and organic matter effect, J. Hazard. Mater. 162(2009)503-511. 
[73] S. Tangjuank, N. Insuk, J. Tontrakoon, V. Udeye, Adsorption of lead(II) and cadmium(II) ions from aqueous solutions by adsorption on activated carbon prepared from cashew nut shells, Int. J. Chem. Mol. Nucl. Mater. Metall. Eng 28(2009)221-227.

[74] B. Zhao, J.E. Zhang, W. Yan, X. Kang, C. Cheng, Y. Ouyang, Removal of cadmium from aqueous solution using waste shells of golden apple snail, Desalin. Water Treat. (2016)1-17.

[75] S. Tabesh, F. Davar, M.R. Loghman-Estarki, Preparation of $\gamma-\mathrm{Al}_{2} \mathrm{O}_{3}$ nanoparticles using modified sol-gel method and its use for the adsorption of lead and cadmium ions, J. Alloys Compd. 730 (2018) 441-449.

[76] G.O. Abatan, P.A. Alaba, B.A. Oni, K.Akpojevwe, V. Efeovbokhan,·F. Abnisa, Performance of eggshells powder as an adsorbent for adsorption of hexavalent chromium and cadmium from wastewater, SN. Appl. Sci (2020) 2:1996 